\title{
POWER TO THE PEOPLE? THE IMPACT OF THE LOCALISM ACT 2011 ON ENVIRONMENTAL JUSTICE IN ENGLAND
}

\author{
Frances Bodman*
}

\begin{abstract}
The Localism Act 2011 is a wide-ranging piece of legislation which is part of the current government's drive towards creating 'the Big Society'. Part 6 of that Act concerns changes to the planning system and represents a radical departure from the system that has developed over the last 60 years. Amongst other changes, it abolishes Regional Spatial Strategies and introduces Neighbourhood Planning. These changes will affect the way that decisions about the distribution of desirable and undesirable land-uses in England are made and they therefore raise questions about environmental justice. This paper uses the concept of environmental justice to analyse the provisions and underpinning ideology of the Localism Act. In concluding I find that both these changes have the potential to have a negative effect on environmental justice. Both are liable to increase the disparity between rich and poor communities.
\end{abstract}

\section{A. INTRODUCTION}

The Localism Act 2011 (Localism Act) is a wide-ranging piece of legislation which is part of the current government's drive towards creating 'the Big Society'. When introducing the Localism Bill into the House of Commons in 2011 the Secretary of State for Communities and Local Government, Eric Pickles, stated that it would "reverse the centralist creep of decades and replace it with local control [...] revitalising local democracy and putting power back where it belongs, in the hands of the people."1

However, localism is a flexible term, which allows those with radically different political views to champion their own version of it. The malleability of this concept masks the wide variety in the detail attributed to it by different political parties. There is actually no consensus on either the concept itself or how it should be implemented. Further, the planning regime in England has historically been one of the most volatile areas of policy. Successive governments have continually changed the way decisions about land-use and strategic planning are made. There has, however, been a general movement away from centralised decision-making towards more localised administration of power.

\footnotetext{
* Solicitor, LLM Environmental Law and Policy (University College London). I would like to thank Professor Jane Holder for her assistance during the preparation of this paper. All errors and omissions are my own.

${ }^{1}$ HC deb 17 January 2011, vol 521, col 558.
} 
Part 6 of the Localism Act concerns the latest changes to the planning system and represents a radical departure from the system that has developed over the last 60 years. Amongst other changes, it introduces the Community Infrastructure Levy, abolishes the Infrastructure Planning Commission, abolishes Regional Spatial Strategies (RSSs) and introduces Neighbourhood Planning. Each of these changes will affect the way that decisions about the distribution of desirable and undesirable land-uses in England are made. All of these changes therefore raise questions about environmental justice in England. This paper will concentrate on the last two changes, the abolition of RSSs and the introduction of neighbourhood planning, and relate them to the concept of environmental justice.

Environmental justice is a concept that emerged in America during the 1970s as a result of some highly publicised and serious pollution incidents which disproportionately affected certain sectors of the population. ${ }^{2}$ Broadly put, it is the concept that all people, regardless of race, gender, age or socio-economic status should have equal access to environmental benefits and should not be disproportionately subjected to environmental burdens and that they should have the opportunity to participate in and influence environmental decisions that affect them. Environmental justice is an anthropocentric idea of justice, which concentrates on the relationship between environmental impacts and the communities affected.

This paper uses the concept of environmental justice to analyse the provisions and underpinning ideology of the Localism Act. It first discusses the issue of environmental justice, in particular how the concept manifests itself in England and how the planning system is at the heart of these issues. It then considers the theory of 'localism' and where the current crusade for more local decision-making may originate. This is followed by an examination of RSSs and the mechanisms set out in the Localism Act and beyond that may go some way to replacing them and the effects of these changes on environmental justice.

Finally, the paper sets out the provisions relating to neighbourhood planning and considers how such provisions may affect environmental justice. In concluding, the paper finds that both the abolition of RSSs and the introduction of neighbourhood planning have the potential to have a negative effect on environmental justice. Both are liable to increase the disparity between rich and poor communities. It finds that the abolition of RSSs is likely to

\footnotetext{
${ }^{2}$ Examples include siting of a PCB Landfill at Warren County (see <http://www.ncpcbarchives.com/>), and schools and houses built on a toxic waste dump at Love Canal, New York (see $<$ http://en.wikipedia.org/wiki/Love_Canal>).
} 
have a particular effect on distributive justice whilst neighbourhood planning may decrease both the procedural and distributive elements of environmental justice.

\section{B. ENVIRONMENTAL JUSTICE IN ENGLAND}

\section{Origins of Environmental Justice}

The environmental justice movement in America is widely accepted to have begun with the protests in Warren County, North Carolina over the dumping of polychlorinated biphenyls (PCBs). The mainly African-American community affected used non-violent civil disobedience methods, similar to those used by the civil rights movement, to protest about the effects of the dumping of this toxic material near their community. ${ }^{3}$ The concept of environmental justice moved on at pace in America and had important (in principle) legal impacts. Most notably, in 1994 then president Clinton made Executive Order 12898 entitled "Federal actions to address environmental justice in minority populations and low income populations". ${ }^{4}$ This required all federal agencies to address environmental justice issues in the making of their programmes and policies. This was a symbolically important achievement for the environmental justice movement and had the potential to make real strides towards more just outcomes. However, in its 2007 report the United Church of Christ chronicled the systematic rolling back of environmental justice initiatives over the last decade and found that twenty years after its seminal study ${ }^{5}$ the "conclusions are very much the same". 6

Development of the environmental justice concept outside America has been much slower and it is still not a commonly addressed issue in Europe. ${ }^{7}$ Research by various civil society groups in the $\mathrm{UK}^{8}$ is more advanced than in the rest of Europe but the concept is still in its infancy compared to its American counterpart. Nonetheless, from the research that is available in the UK it is evident that environmental injustices are occurring throughout the country in a number of different contexts. Evidence suggests that the effects of flooding are felt disproportionately by poorer communities ${ }^{9}$ whilst ethnic minority communities suffer

\footnotetext{
3 ibid.

${ }^{4}$ Executive Order 12898 of 11 February 1994.

${ }^{5}$ United Church of Christ Commission for Racial Justice, Toxic Wastes and Race in the United States (United Church of Christ 1987).

${ }^{6}$ United Church of Christ Justice and Witness Ministries, Toxic Wastes and Race at Twenty 1987-2007 (United Church of Christ 2007).

7 Julian Agyeman, 'Constructing Environmental (in)Justice: Transatlantic Tales' (2002) 11 Environmental Politics 31.

${ }^{8}$ e.g. Capacity Global, the Black Environment Network, and Friends of the Earth.

${ }^{9}$ Gordon Walker et al, Environmental Quality and Social Deprivation (Environment Agency 2003).
} 
from a lack of access to the countryside ${ }^{10}$ and disproportionately from noise and air pollution. ${ }^{11}$ The concept of environmental justice in the UK is starting to gain momentum and more mainstream political support. ${ }^{12}$

Differing backgrounds and historical settings mean that different countries will experience distinctive approaches to activism and justice. Agyeman states that "[e]nvironmental justice can and does mean something different in the UK to what it means in the US" ${ }^{13}$ as well as other countries. The difference in interpretation demonstrates the inherent local nature of environmental justice. It is discrepancies in the harm caused to local living environments and communities by environmental decisions and the differing impact of local policies that are indicators of environmental injustices.

\section{Dimensions of Environmental Justice}

Environmental justice is a "multifaceted concept" 14 encompassing a wide range of issues, and Agyeman states that "the concept is much broader today than when it was initially coined". ${ }^{15}$ However, the issues tend to fall into two categories: procedural and distributive.

Procedural justice refers to non-discrimination of those who are able to participate in and have an effect on environmental decisions which affect them. Distributive justice relates to the siting of, and access to, environmental benefits such as parks and green spaces and environmental burdens such as waste installations and chemical plants. In America there has tended to be an emphasis on the distributive elements of the concepts, perhaps because of the origins of the movement. However, in Europe the concept began to emerge at the same time as the implementation of the Aarhus Convention and its three pillars: access to environmental information; participation in environmental decision-making; and access to justice in environmental matters. This convergence has meant that in Europe the procedural elements of environmental justice have always taken precedence over the distributive aspects. In fact, Krämer notes that the ECJ has never had to decide a case where the siting of a facility or an

\footnotetext{
10 Julian Agyeman, 'Ethnic Minorities in Britain: Short Change, Systematic Indifference and Sustainable Development' (2001) 3 Journal of Environmental Policy and Planning 15.

${ }^{11}$ Karen Lucas et al, Environmental and Social Justice: Rapid Research and Evidence Review (Sustainable Development Research Network 2004) 72.

${ }^{12}$ For example see speech given by the then Scottish First Minister, J McConnell, Edinburgh, 2002.

${ }^{13}$ Agyeman (n 7) 43.

${ }^{14}$ Ole Pedersen, 'Environmental Justice in the UK: Uncertainty, Ambiguity and the Law' (2011) 31 Legal Studies 279, 284.

${ }^{15}$ Agyeman (n 7) 34.
} 
infrastructure project had been questioned, because it had been located in a place which disproportionately burdened low-income or minority groups". ${ }^{16}$

A further aspect of the procedural element of environmental justice is that of 'recognition'. Schlosberg states that "there is a crucial link between a lack of recognition and the inequitable distribution of environmental bads; it is a general lack of value of the poor and people of color that leads to this distributional inequality". ${ }^{17}$ Further, Harper et al state that "poor and minority communities have often been misrecognized as indifferent to environmental issues". ${ }^{18}$ This lack of recognition is illustrated in the UK by the dominance of "white, middle class professionals" 19 in the mainstream environmental movement and the under-representation of all other groups.

In parallel with the implementation of the Aarhus Convention, the concept of 'sustainable development' came to the foreground of global environmental policy making. In the UK environmental justice "is generally seen as an integral part of sustainable development". ${ }^{20}$ Land-use planning plays an important role in ensuring that development is sustainable and as such is crucial to ensuring environmental justice. The way that the planning system can contribute to environmental justice will be discussed in the next section but in order to analyse this in context, the evolution of the planning system in England will be examined first.

\section{THE THEORY OF LOCALISM}

Broadly speaking, 'localism' is the simple concept that locally elected authorities are better placed to make decisions relating solely to the local area than central government. This idea is far from an innovative creation of recent governments. In his 1862 work, JS Mill stated that "[i]t is but a small portion of the public business which can be well done or safely attempted by the central authorities". ${ }^{21}$ More recent manifestations can be seen in the embodiment of this concept in Article 1 TEU, which states that decisions should be taken "[...] as closely as possible to the citizen".

\footnotetext{
${ }^{16}$ Ludwig Krämer, 'Environmental Justice in the European Court of Justice' in Jonas Ebbesson and Phoebe Okowa (eds) Environmental Law and Justice in Context (CUP 2009).

${ }^{17}$ David Schlosberg, Defining Environmental Justice: Theories, Movements, and Nature (OUP 2007) 60.

${ }^{18}$ Krista Harper, Tamara Steger and Richard Filčák, 'Environmental Justice and Roma Communities in Central and Eastern Europe' (2009) 19 Environmental Policy and Governance 251, 254.

${ }^{19}$ Agyeman (n 10) 16.

${ }^{20}$ Pedersen (n 14) 292.

${ }^{21}$ John Stuart Mill, Considerations on Representative Government (Harper 1862) 286.
} 
Although there is no agreed upon theoretical justification for local government, there are two general hypotheses that have been suggested. The first is that central governments cannot acquaint themselves with the minutiae of every local situation to the same level that a locally elected authority can. Therefore, when it comes to providing solutions for local issues and providing local services, such locally elected authorities are best placed to achieve optimum local solutions. Secondly, local government adds to democracy by allowing for increased participation in government. This theory contends that local government has an inherent ethical value rather than simply being a mechanism for improving the performance of the central government.

These two theories sit rather unhappily together and contribute to the "ambiguity" 22 of the role of local government. If the role of local authorities is one of service provision as a type of agency for central government, then one would expect central standards to be set and uniformity in the services provided. However, if the role of local government is a democratic one, then this implies a choice on the part of the public and diversity of services between locales. This tension is accentuated by the apathy shown by the British citizenry when it comes to local elections. Turnout at these elections has been consistently low - at the elections in 2012 it was at around 30 per cent. ${ }^{23}$ Considering such public disengagement with the outcome of these elections, the representative - and therefore democratic - credentials of local authorities are questionable. This lack of interest in local government is not a recent development: in 1967 it caused the Maud Committee to report that "the local administration of public services is essential, that the organs of administration should be democratically elected bodies is not". ${ }^{24}$ Despite this, there has been no momentous shift in the way local government is structured since that report, but successive recent governments have created new policies based on "ultra-local mechanisms". ${ }^{25}$

The most recent manifestation of this localisation of governance is the Localism Act, which gives local authorities a general power of competence as well as giving unprecedented powers to representative groups at the neighbourhood level. This is described by the Conservative party as a "massive transfer of power from Whitehall to local communities"26 and is designed to encourage community involvement and participation. In reality, however, it is questionable whether the coalition's version of localism will achieve its aims of

\footnotetext{
${ }^{22}$ David Walker, Living With Ambiguity: The Relationship Between Central and Local Government (Joseph Rowntree Foundation 2000).

${ }^{23}$ See <http://www.parliament.uk/briefing-papers/SN01467/elections-turnout>.

${ }^{24}$ Maud Committee, The Report of the Committee on the Management of Local Government, HMSO, 1967, 68.

${ }^{25}$ Walker (n 22) 11.

${ }^{26}$ See <http://www.conservatives.com/>.
} 
'community empowerment'. Catney et al distinguish between "positive localism", where the state plays an important facilitating role in the operation of civil society, and the "negative localism" of the current government with its emphasis on self-sufficiency. ${ }^{27}$ These are two quite different concepts of localism, with the first having an underlying principle of equality and minimum standards while the second actively encourages difference and tailor made solutions to location specific issues.

Purcell has pointed to the danger of falling into the "local trap". ${ }^{28}$ That is that it is often assumed that smaller scales are inherently more just. He argues that this is simply not the case and that any scale of governance can be just depending on the specific circumstances and that there are many circumstances in which a local level of governance will produce unjust results. In addition, implementation of a local level of governance is often mistakenly seen as an end to be achieved in itself, rather than as a means by which to achieve more democratic or just decision-making. The coalition's version of localism seems to fall squarely into this category with "little analysis of the structural impediments which affect particular social groups and communities and how particular flows and connections lock certain groups out". ${ }^{29}$ Further, Parvin suggests that localism can lead to a "benign yet systematic marginalisation of minority interests". ${ }^{30}$ This is because by allowing a majority to make decisions, those outside the majority will be continuously outvoted, leading to injustices. He points out that one role of representative government is to make just but unpopular decisions and that localism removes this ability. These issues are explored below with regard to the new governance structures for the planning system.

\section{REGIONAL SPATIAL STRATEGIES AND STRATEGIC PLANNING UNDER THE LOCALISM ACT}

\section{Regional Governance}

The regional level of governance in the planning system was introduced by the Planning and Compulsory Purchase Act (PCPA) in 2004 by the New Labour government. Its evolution began some time before this, towards the beginning of the Blair era. Shortly after coming to

\footnotetext{
${ }^{27}$ Philip Catney et al, 'Big Society, Little Justice? Community Renewable Energy and the Politics of Localism' (2013) Local Environment 1.

${ }^{28}$ Mark Purcell, 'Urban Democracy and the Local Trap' (2006) 43 Urban Studies 1921.

${ }^{29}$ Catney et al (n 27) 3.

${ }^{30}$ Phil Parvin, 'Against Localism: Does Decentralising Power to Communities Fail Minorities?' (2009) 80 The Political Quarterly 351, 357.
} 
power, the Blair government commissioned a White Paper ${ }^{31}$ following its manifesto commitment to devolve greater power to the regions. This eventually resulted in the Regional Development Agencies Act 1998.

These developments took place following the Rio 1992 Earth Summit and in the context of the emerging mantra of sustainable development and the need to integrate environmental and social issues into decisions about economic growth and development. Regional Development Agencies (RDAs) had a strategic role in developing policy at a "larger than local" level and one of their roles was to "place sustainable development at the heart of their programmes". ${ }^{32}$ The introduction of RSSs followed a progressive move towards greater autonomy for regional governance structures. They constituted a strategic framework for spatial planning at a regional level.

Advocates of RSSs point to the cooperation produced between local authorities and the enhanced ability they provided for dealing with unpopular planning decisions. ${ }^{33}$ However, there have been a great number of detractors with the main objections relating to the lack of democratic accountability and the top-down imposition of targets, particularly for housing, as well as the length and complexity of the process. ${ }^{34}$

Baker and Wong state that, in terms of regional planning, there was a "general failure to deliver on the ideals of its advocates" 35 and that the general perception was that the purpose of RSSs was the "allocation and distribution of regional and sub-regional housing and brownfield land development targets". ${ }^{36}$ Various reasons have been put forward for the failure of the regional scale of governance, from the "lack of workable institutional structure" ${ }^{37}$ to the lack of "public identification" 38 with regional institutions. The absence of public enthusiasm for democratically elected regional bodies was demonstrated by the 2004 North-East referendum on regional assemblies which resulted in an overwhelming vote against the creation of such an institution. This was, in fact, the only referendum ever held and as such sounded the death knell for regional governance in England. In the absence of

\footnotetext{
${ }^{31}$ Department of the Environment, Transport \& the Regions, Building Partnerships for Prosperity: Sustainable Growth Competitiveness and Employment in the English Regions (White Paper, Cm 3814, 1997).

32 ibid 39.

${ }^{33}$ House of Commons Communities and Local Government Committee, Abolition of Regional Spatial Strategies: A Planning Vacuum (Report, HC 517, 2011) 8.

34 ibid 7.

${ }^{35}$ Mark Baker and Cecilia Wong, 'The Delusion of Strategic Spatial Planning: What's Left After the Labour Government's English Regional Experiment?’ (2013) 28 Planning Practice and Research 83, 91.

36 ibid 93.

37 ibid 92.

38 John Fenwick, Janice McMillan and Howard Elcock, 'Local Government and the Problem of English Governance' (2009) 35 Local Government Studies 5, 9.
} 
any democratic process the institutions that were in existence lacked legitimacy and accountability.

\section{E. THE EFFECT OF PLANNING ON ENVIRONMENTAL JUSTICE}

\section{The Evolution of Land-Use Planning in England}

The concept of placing controls on the use of private property dates from the mid-nineteenth century as a response to the large numbers of the newly established working class moving from the countryside to urban areas and the resulting poor living conditions of those workers. ${ }^{39}$ Land ownership in England has traditionally been synonymous with wealth and influence and historically "[c]ontrol of land could not... be readily divorced from power". ${ }^{40}$ Much of the common law of England developed as a result of the use by the landed classes of the courts to decide disputes over land ownership and the governance of estates. Hence, the protection of private property has always held a prominent place in the English legal system and is an inherent principle of English law.

When the government first attempted to impose controls on the use of private property, the inevitable challenges that were bought before the courts by property owners were decided using the existing rules of interpretation. Therefore, whenever possible, statutes were interpreted to favour the property owner and "[j] udgments were couched solely in terms of the need to protect land-owners against hasty government action with no regard being paid to...the property-less". ${ }^{41}$ This has led to an ingrained ideology of the protection of private property rights in modern English planning law. This ideology competes with the more modern ideologies that planning law exists to advance the public interest and the cause of public participation. ${ }^{42}$

Despite the development of the latter two ideologies, there is still much in English planning law which favours the landowner. In the event of a refusal of a planning application, the applicant is afforded the opportunity to appeal. No such appeal route is available to those who oppose the application in the event of a positive outcome. Further, any such appeal brought by the applicant is officially decided by the secretary of state but, in reality, is heard by the Planning Inspectorate. An unelected, unaccountable body can therefore overrule the decision of the democratically elected Local Planning Authority (LPA).

\footnotetext{
${ }^{39}$ William Ashworth, The Genesis of Modern British Town Planning (Routledge 1954).

${ }^{40}$ John H Baker, An Introduction to English Legal History (OUP 2007) 223.

${ }^{41}$ Patrick McAuslan, The Ideologies of Planning Law (Pergamon Press 1980) 3.

42 ibid 2.
} 
In accordance with the third ideology, public participation is an important element of the planning system in England and generally takes the form of consultation. However, particularly when an environmental impact assessment is required, the developer is in almost complete control of the provision of the information which forms the basis of consultation. The developer must produce an environmental statement which should constitute "a single and accessible compilation" 43 and include a non-technical summary. ${ }^{44}$ The purpose of this non-technical summary is to allow for meaningful participation by the public. However, critics have suggested that developers use them as a "public relations exercise" 45 and that even whilst using the language of the legislation, they address non-environmental issues such as the creation of jobs and bolstering the local economy. ${ }^{46}$

When assessing planning applications, the LPA must have regard to all material considerations, one of which is the development plan which may include a Local Development Plan (LDP). ${ }^{47}$ The LDP sets out policies relating to land-use within the administrative area of an LPA and sets out how the LPA intends to meet the future needs of the local area. An LDP will generally cover such things as housing, schools, waste facilities, and transport, but does not negate the need for a planning application in relation to any specific proposal. The LDP is an immensely important document for both local communities and developers. Allocation of land in the LDP for a particular purpose is fundamental to the chances of success of a future planning application and will have a significant effect on its value. As such, there is a huge amount at stake for developers in the LDP process. Conversely, for local communities the stakes may not be economic, but the allocation of land reduces the chances of successful opposition to development.

\section{Justice in the Planning System}

According to Salkin, "[e]nvironmental justice goes to the core of traditional land use decisions". ${ }^{48}$ This is because it is the planning system that is used to decide where undesirable land-uses are sited as well as how such decisions are made and who is involved in the

\footnotetext{
${ }^{43}$ Lord Hoffman, Berkeley $v$ Secretary of State for the Environment, Transport and the Regions and Fulham Football Club (No1) [2001] Env LR 16, para 9.

${ }^{44}$ Town and Country Planning (Environmental Impact Assessment) (England and Wales) Regulations 1999, Sch 4 Pt 1 (6).

${ }^{45}$ Maria Lee, European Union Environmental Law, Governance and Decision-Making (2nd edn, Hart Publishing 2014).

${ }^{46}$ Jane Holder, 'The Prospect for Ecological Impact Assessment' in Jane Holder and Donald McGillivray (eds) Taking Stock of Environmental Assessment: Law, Policy and Practice (Routledge-Cavendish 2007) 273.

${ }^{47}$ For definition of development plan see Planning and Compulsory Purchase Act 2004 (PCPA 2004) s 38.

${ }^{48}$ Patricia Salkin, 'Intersection Between Environmental Justice and Land Use Planning' (2006) 58 Planning and Environmental Law 3.
} 
decision-making process. The planning system therefore plays an important role in establishing both distributional and procedural equity when it comes to land-use. Further, how individuals identify with the places they live and how decisions are made about changes to such places are fundamental concerns of modern society. As discussed above, the traditional environmental movement has been dominated by the white middle-classes; however, research clearly shows that both disadvantaged ${ }^{49}$ and ethnic minority ${ }^{50}$ communities have concerns about the environment, particularly at a local level concerning the places they live. The use to which land is put can be essential to the wellbeing of the community in which it lies and the character of the area.

As discussed above, the English planning system very much favours the landowner or developer. In general, the system is a reactive one. A landowner will propose a use or development on his land and a decision will be made as to whether such use or development is appropriate. At some point during that decision the 'public' will be consulted; however, the scope for influence is limited, as results of consultation must be considered - but not necessarily followed. This is true of individual applications as well as in the formation of an LDP.

The LDP process is a complicated and technical one. It involves the collection of evidence with regard to the need as well as sustainability and deliverability of developments. Most of the information on which an LPA will base its decisions is provided by the developer. This automatically puts the developer in a position of power. Additionally, the stake for the developer is financial, and as such, the cost of participation is built into its business plan. This is not the case for individual participants or groups. Further, the developer is likely to have existing expertise and experience of the process, thereby reducing the overall cost of participation. This is because the developer is what Galanter describes as a "repeat player" in the planning process whereas the would-be objector is a "one-shotter". ${ }^{51}$ Galanter's analysis of the relative position of these sets of players within a legal context can further be applied to the planning process.

This is a classic situation where, in general, the developer will be bigger, wealthier, and more powerful than a community group which opposes a development. The developer's objectives in the planning process will not be singular. It may own several sites within one

\footnotetext{
${ }^{49}$ See Kate Burningham and Diana Thrush, Rainforests are a Long Way from Here, the Environmental Concerns of Disadvantaged Groups (Joseph Rowntree Foundation 2001).

${ }^{50}$ See Agyeman (n 10).

${ }^{51}$ Marc Galanter, 'Why the "Haves" Come Out Ahead: Speculation on the Limits of Legal Change' (1974) 9 Law \& Society Review 95.
} 
administrative area and be willing to forgo allocation of one on the basis that the others are allocated for the desired use thereby diminishing the importance of any one plot of land. Conversely, it is likely that the decision over the allocation of one plot of land will be of paramount importance to the objector. Galanter also points to the repeat players' ability to "play for rules as well as immediate gains". ${ }^{52}$ This is true, for example, of a national house builder who may challenge a decision on the basis that it has implications for other decisions in which it has an interest. Consequently, there is no level playing field on which such disputes are resolved.

Indeed, the planning system in England has become increasingly positivist in recent years both in terms of individual applications for development and in the creation of development plans. Needs assessments, environmental impact assessments and sustainability assessments are all evidence-based reports of a highly technocratic nature. This scientific approach often fails to take into account the broader concerns of affected communities. A planning application for a landfill site will likely have evidence on potential health risks to local residents in terms of causing cancer or other life threatening illnesses, but is unlikely to have regard to levels of stress and anxiety that can be increased simply due to its presence. ${ }^{53}$ This 'expert' led approach also fails to take account of differing values, especially concerning risk, or deal with uncertainty. ${ }^{54}$ These issues are countered by the requirement for public participation in both the planning process and in environmental impact assessments.

\section{Public Participation}

Participation is now "almost an instinctive response to concerns about legitimacy of decisionmaking" $" 55$ and, particularly in planning decisions, goes some way to counter-balancing the strength of developers in the process. Increased participation is advocated on both procedural and substantive grounds. It is argued that participation increases the democratic credentials of decisions as well as the quality of the outcome. That is, public participation leads to better decisions. $^{56}$

\footnotetext{
52 ibid, 100.

${ }^{53}$ For discussion see Raul P Lejano and Daniel Stokols, 'Understanding Minority Residents' Perceptions of Neighborhood Risk and Environmental Justice: New Modalities, Findings, and Policy Implications' (2010) 27 Journal of Architectural and Planning Research 107. See also The Royal Commission on Environmental Pollution, Setting Environmental Standards (21st Report, Cm 4053, 1998), para 4.25.

${ }^{54}$ See RCEP, ibid chap 4.

${ }_{55}^{55}$ Maria Lee, EU Environmental Law: Challenges, Change and Decision-Making (Hart Publishing 2005$) 113$.

${ }^{56}$ For discussion see Jenny Steele, 'Participation and Deliberation in Environmental Law: Exploring a ProblemSolving Approach’ (2001) 21 Oxford Journal of Legal Studies 415.
} 


\section{Power to the People? The Impact of the Localism Act 2011 on Environmental Justice in England}

This is because planning decisions often greatly affect a small group of people living in a particular area. It is therefore particularly important in planning decisions to engage with the public in order to attain local knowledge ${ }^{57}$ The siting of unwanted land-uses inevitably causes controversy and opposition from the "host community". ${ }^{58}$ Steele states that participation must "begin with the idea that citizen input is both needed and valued, rather than with the perception that the citizen should be "allowed' to be present". 59 This is true because those affected by a decision will have particular concerns which may not have been addressed or considered by the developer or the decision-maker. They may also be able to suggest solutions to problems that those more remote from the issues would not have thought of.

Increased participation has long been used as a justification for localism ${ }^{60}$ on the basis that "participation is a diminishing function of scale". ${ }^{61}$ That is, the greater and more immediate the potential impact of any particular decision, the more likely a person is to participate. This is because participation takes time and often has associated costs. Further, the more locally a decision is being taken the greater the potential to influence that decision. This is because decisions relating to large projects, such as the HS2 rail link, are made at a high political level with a national agenda in mind. It is therefore likely that the impact of public participation in such decisions is significantly diminished. This theory will be examined further in the next section.

\section{Regional and Sub-Regional Planning under the Localism Act}

The abolition of RSSs, along with the RDAs which produced them, has left a gap in the governance system of planning in England. RSSs have not been replaced and, as such, there is now no relevant spatial planning document bridging the gap between the newly introduced National Planning Policy Framework (NPPF) and the LDP (if one exists).

Some of the previous functions of RDAs have been taken on by the newly established Local Enterprise Partnerships (LEPs). The abolition of RDAs and the creation of LEPs were announced in the 2010 Budget. ${ }^{62}$ The announcement suggests that LEPs are a mechanism to

\footnotetext{
${ }^{57}$ See for example Frank Fischer, Citizens, Experts, and the Environment: The Politics of Local Knowledge (Duke University Press 2000).

${ }^{58}$ See Neil Stanley 'Contentious Planning Disputes: An Insoluble Problem?' (2000) Journal of Planning and Environment Law 1226.

${ }^{59}$ Steele (n 56) 429.

${ }^{60}$ See LJ Sharpe, 'Theories and Values of Local Government' (1970) Political Studies 153, 158.

${ }^{61}$ ibid 160.

${ }^{62}$ HM Treasury, Budget 2010 (Budget, HC 61, 2010) 31.
} 
aid the cooperation between local authorities and local businesses in order to achieve local economic growth. The Government's vision for LEPs was expanded upon in its White Paper, Local Growth. ${ }^{63}$ It is clear that planning is intended to form a part of the LEPs' function; however, the question of whether they are intended, or able, to fulfil a strategic planning role has been met with "considerable scepticism". ${ }^{64}$ The function of LEPs is deliberately not defined in legislation as the Government envisages that they will "differ across the county in both form and function in order to best meet local circumstances". ${ }^{65}$ However, the prominence of 'enterprise' in their name, the fact that it is intended that business representatives form at least half the board, and the fact that a prominent business leader should be chairman ${ }^{66}$ are clear indications of the primacy of economic concerns in the role of LEPs. This is in stark contrast to RDAs, where achieving sustainable development was a priority.

There are currently 39 LEPs, in contrast to the nine RDAs that previously existed. This is indicative of the Government's intention that LEPs be based on functional economic areas as opposed to administrative boundaries. This follows a general trend within the EU towards administration of "soft spaces" 67 based on functional regions that "look beyond their administrative borders". ${ }^{6}$

\section{Duty to Cooperate}

The Localism Act imposes a duty on LPAs to cooperate in relation to the planning of sustainable development. This duty specifically relates to decisions that are "strategic" 69 which may have a "significant impact on at least two planning areas". ${ }^{70}$ There is, therefore, potential that this duty may act as a quasi-regional strategic planning mechanism by requiring consultation and on-going engagement between neighbouring LPAs. However, it is not clear to what extent this duty is enforceable, ${ }^{71}$ or how this might be imposed in practice. In the

\footnotetext{
${ }^{63}$ Department of Business, Innovation \& Skills, Local Growth: Realising Every Place's Potential (White Paper, $\mathrm{Cm}$ 7961, 2010).

${ }^{64}$ HOC Committee (n 33) 31.

${ }^{65}$ BIS (n 63) 14.

66 ibid.

${ }^{67}$ For discussion see Philip Allmendinger and Graham Haughton, 'Soft Spaces, Fuzzy Boundaries, and Metagovernance: The New Spatial Planning in the Thames Gateway' (2009) 41 Environment and Planning A 617.

${ }^{68}$ Commission of the European Communities, Territorial Agenda of the European Union 2020: Towards and Inclusive, Smart and Sustainable Europe of Diverse Regions (CEC 2011).

${ }^{69}$ PCPA 2004 s 33A(3).

${ }^{70}$ PCPA 2004 s 33A(4).

${ }^{71}$ See Lee Purgalis and Alan Townsend, 'Rescaling of Planning and its Interface with Economic Development' (2013) 28 Planning Practice and Research 104, 115.
} 
absence of any concrete statutory guidance on how this duty is to be implemented, there remain serious doubts about its effectiveness.

In its inquiry into the abolition of RSSs, the House of Commons Communities and Local Government Committee heard evidence relating to the proposed duty to cooperate as drafted in the Localism Bill. ${ }^{72}$ The committee points to several weaknesses of the duty. There is no definition of a failure to cooperate and no sanction for any such failure or details of how conflicts should be resolved in the event that local authorities cannot resolve them between themselves. In a powerful statement the report notes that the "vocabulary of aspiration and encouragement $[\ldots]$ with vague and imprecise references to future central Government guidance [...] strikes us as bad law, poorly conceived, and shoddily drafted". ${ }^{73}$ Another issue may arise in the context of negative decisions. It is not clear what the duty would imply if an LPA decides not to take forward a development which would have been a strategic matter. Such a decision may well have a significant impact on a neighbouring authority; however, it is not clear that there would be a duty to consult on it. The committee concluded that there was a need, which had been acknowledged by the Government, to strengthen the duty to cooperate. It is not apparent that the subsequent amendments satisfactorily address these issues. The Planning Advisory Service's guide to LPAs states that it is up to the Planning Inspectorate to assess whether the duty has been complied with but that there is no set format for demonstrating such compliance. It is further up to the Planning Inspectorate to deal with any failure in the duty. ${ }^{74}$ There is no guidance as to what criteria the Planning Inspectorate will use to interpret the still vague and uncertain wording of the duty to cooperate or how it will ensure a consistent interpretation. The effect of these changes to the governance system will be examined in the next section.

\section{F. THE EFFECT OF A LACK OF REGIONAL PLANNING GOVERNANCE ON ENVIRONMENTAL JUSTICE}

\section{Sustainable Development}

Sustainable development has been at the forefront of government policy for many years and it is clear that the Coalition Government wishes to portray its enduring commitment to this concept. In a speech to the RTPI the then minister for Communities and Local Government

\footnotetext{
${ }^{72}$ HOC Committee (n 33) 26.

73 ibid 29.

${ }^{74}$ See <http://www.pas.gov.uk/web/pas-test-site/strategicplanning\#contents-8>.
} 
emphasised his intention to "champion sustainable development" ${ }^{75}$ However, it is not clear how, if at all, this dovetails with the Government's rhetoric of "growth at any cost" and the Chancellor of the Exchequer's statement to the cabinet that "anything that gets in the way of growth will be flattened" ${ }^{76}$ This is contrary to the principles of sustainable development: that a balance must be found between economic, social and environmental concerns. ${ }^{77}$

RSSs were subject to a Sustainability Appraisal, which encompassed the requirements of a Strategic Environmental Assessments required by EU law. ${ }^{78}$ Sustainability appraisals are intended to aid in the delivery of sustainable development and are open to public participation. Other levels of development plans are equally subject to sustainability appraisals; however, by removing this layer of plan it is likely that a huge amount of evidence as to sustainability, particularly in the assessment of alternatives, may be lost or never gathered. Further, by losing this opportunity for public participation the added value that is achieved by such processes is lost. The duty to cooperate now imposed on local authorities will not be subject to the rigours of a sustainability appraisal or even a strategic environmental assessment. This could lead to less-than-optimal strategies being followed for want of viable alternatives, as well as less just outcomes.

As discussed above, LEPs may take on part of the role of RDAs; however, it is not obvious how these bodies will contribute to sustainable development. The economic focus is so evident that it is unlikely that environmental or social matters will be given much consideration unless there is an obvious and immediate economic benefit in doing so. This is not a new mind-set: historically, environmentalists have struggled against the notion that environmental protection can only be achieved following economic growth ${ }^{79}$ and that the two are incompatible aims. This is in total contradiction to the aims of sustainable development and it is perhaps clear now that when the current Government says sustainable development, what it means is sustainable (or endless) growth. ${ }^{80}$

\section{Centralism in (thinly veiled) Disguise}

75 Greg Clark, 'A New Settlement for Planning, Speech to the RTPI', June 2011, <www.gregclark.org/articles $\sim$ speeches/articles $\sim$ speeches/a-new-settlement-for-planning-a-speech-to-the/38> accessed 6 August 2014.

${ }^{76}$ George Osborne quoted in Tom Burke, 'From The Greenest Government Ever...To Our Very Own Tea Party' (2011) 441 ENDS Report 55.

77 Johannesburg Declaration A/CONF. 199/20.

78 Directive 2001/42/EC on the Assessment of the Effects of Certain Plans and Programmes on the Environment.

${ }^{79}$ There is a vast amount of literature on this subject, see for example David I Stern, 'The Rise and Fall of the Environmental Kuznets Curve' (2004) 32 World Development 1419.

${ }^{80}$ For discussion of the limits of growth see Andrew Dobson, Green Political Thought (Routledge 2007 ), ch 3. 
With the abolition of RSSs, many strategic decisions will now be made in accordance with the NPPF. The "golden thread" 81 running through the NPPF is the presumption in favour of sustainable development. This means that development can only be refused where the adverse effects of not doing so are "significant and demonstrable" 82 or where there are specific policies within the NPPF itself which indicate that such development should be restricted. This puts a significant evidential burden on opponents of development, particularly where there is no current LDP. There are large numbers of LPAs that do not have an up to date LDP. In the absence of an LDP, the only strategic guidance available to LPAs is the NPPF. This could have significant influence on the distribution and siting of undesirable land-uses. When preparing corporate strategies developers may feel that, where there is no LDP, they have more flexibility with regard to location. This could lead to developers favouring administrative areas without an LDP (likely to be the most deprived areas) as they feel their planning application will face fewer obstacles or that they will have a better chance of a positive outcome on appeal should their application be refused. This could have a significant adverse effect on environmental justice as decisions become based on inappropriate considerations.

The Planning Inspectorate's role has already been broadened by the abolition of RSSs as it is now responsible for more strategic decisions, particularly relating to large infrastructure projects. If there is also a consequential increase in the number of appeals being heard at a central level, the veneer of localism starts to slip. National political parties have strongholds, areas they are never going to win, and areas in contention. If such political considerations begin to play a part in the planning process, particularly in the siting of unwanted land-uses, distributive justice may be affected and an equitable result becomes less likely. Further, the opportunities for participation when decisions are made at a central level are fewer and require increased effort and cost on the part of the participant. In reality, participation at this level is likely to be restricted to organised groups. The level of procedural justice and democratic accountability for these decisions is therefore radically decreased.

\section{Target Setting}

Much of the criticism of RSSs was due to the top-down imposition of targets, particularly for housing. The Coalition's alternative approach is to provide incentives for development such

\footnotetext{
${ }^{81}$ Department for Communities and Local Government, National Planning Policy Framework (Crown Copyright 2012) 04.

82 ibid.
} 
as the New Homes Bonus, ${ }^{83}$ and for decisions to be made locally about the number of new homes to be built. There is concern that this new localised scale will lead to a significant shortfall in the number of new houses. Research from Tetlow King ${ }^{84}$ suggests that since the abolition of RSS there has been a significant decline in the number of new houses being planned for by LPAs. ${ }^{85}$ The House of Commons Committee questioned whether the Government's dual aims of increasing the number of houses being built and the promotion of localism are compatible. Further, they state that "[n]o evidence was produced to support the Government's view that local authorities will achieve comparable rates of house building to those in the past, let alone an increase". ${ }^{86}$ All the evidence suggests that locally assessed housing requirements do not add up to the national need in terms of either numbers or type of housing. If the Government does not achieve an increase in house building, and particularly affordable housing, the effects will undoubtedly be shouldered by the most deprived members of society.

\section{G. NEIGHBOURHOOD PLANNING}

The second major change in the governance of the planning system in the Localism Act was to give neighbourhoods the ability to create their own plans. There are two main aspects of neighbourhood planning introduced by the Localism Act; these are the Neighbourhood Development Order (NDO) and the Neighbourhood Development Plan (NDP). Schedule 9 of the Localism Act inserts provisions into both the Town and Country Planning Act $1990^{87}$ (TCPA) and the PCPA. ${ }^{88}$

Both the NDO and NDP require a "qualifying body" to initiate the process. A qualifying body can be either a parish council or (where none exists) an organisation or body designated as a neighbourhood forum. The process of establishing a qualifying body is therefore relatively simple in areas where there is a parish council. For other areas, the process is more cumbersome. An LPA may designate an organisation or body as a neighbourhood forum if it is satisfied that it meets four prescribed conditions. Those conditions are: that it is established for the express purpose of promoting or improving the

\footnotetext{
83 See HM Government, 'Policy Increasing the number of available homes' <https://www.gov.uk/government/policies/increasing-the-number-of-available-homes/supporting-pages/newhomes-bonus> accessed 6 August 2014.

${ }^{84}$ Cited in HOC Committee (n 33) 36.

85 The report also notes the Government's rejection of this research.

${ }^{86}$ HOC Committee (n 33) 57.

87 Town and Country Planning Act 1990 (TCPA 1990) ss 61E-61Q.

${ }^{88}$ PCPA 2004 ss 38A-C.
} 
social, economic and environmental wellbeing of an area that consists of, or includes the neighbourhood area concerned; that its membership is open to individuals who live or work in the neighbourhood area concerned or are elected members of a county council, district council or London borough council; that it has a minimum of 21 members; and that it has a written constitution. When determining whether to designate an organisation or body the LPA must have regard to the make-up of the membership and whether it is drawn from different places in the neighbourhood and different sections of the community and whether its purpose reflects the character of the area. An LPA must also designate the neighbourhood area. The procedural requirements of designation of both a neighbourhood area and a neighbourhood forum, such as the need for publicity, are expanded upon in the Neighbourhood Planning (General) Regulations 2012. Once a qualifying body and a neighbourhood area are established, the process for an NDO and an NDP can be initiated.

An NDO is an order which grants permission for any development or class of development specified in the order and may relate to all land in the neighbourhood area or a specified area. The NDP provisions of the Localism Act allow the qualifying body to create a plan for the neighbourhood area, which forms part of the development plan documents required to be considered in accordance with s38 PCPA. An NDP must be broadly in line with the strategic objectives of the relevant LDP and it cannot provide for less development than the LDP. Furthermore, prior to its adoption by the LPA, the NDP must be approved by a majority of the community in a referendum.

These new aspects of the planning system are likely to have wide-ranging, and potentially unintended, consequences. The effects of these changes on environmental justice are likely to be profound; some of these impacts will be discussed below.

\section{H. THE IMPACT OF NEIGHBOURHOOD PLANNING ON ENVIRONMENTAL JUSTICE}

\section{Delineating the Neighbourhood Area}

The new S61G of the TCPA deals with the meaning and designation of the "neighbourhood area". This section provides that an LPA may designate an area within the boundaries of its administrative area upon receiving a valid application from either a parish council or a neighbourhood forum. In determining an application for such a designation, the LPA must have regard to: "(a) the desirability of designating the whole area of a parish council as a 
neighbourhood area; and (b) the desirability of maintaining the existing boundaries of areas already designated as neighbourhood areas". 89

Some of the issues arising from this discretion are dealt with in the recent case regarding the Daws Hill neighbourhood in High Wycombe. ${ }^{90}$ This case relates to an application from the Daws Hill Neighbourhood Forum for the designation of the neighbourhood area and the LPA's decision to exclude two strategic sites from the area designated. The neighbourhood forum made an application which included two large brownfield sites which are due to be redeveloped. The LPA excluded these sites on the basis that their redevelopment would have a "wider sphere of influence" 91 than on the immediate neighbourhood and stated it was not in the "interests of the investment of time, energy and costs" 92 for the strategic sites to be included. Arguments were raised by the applicants that the exclusion of such strategic sites would frustrate the purpose of the Localism Act. However, giving judgment for the defendant, Mr Justice Supperstone agreed that the LPA has a "broad discretion when considering whether the specified area is an appropriate area to be designated" $" 93$ and is entitled to consider the resource implications of a neighbourhood area designation. ${ }^{94}$

It remains to be seen what implications this judgment will have on the designation of neighbourhood areas in other situations. It was accepted that although it was not appropriate in this case, "it does not follow that strategic sites cannot be the subject of a Neighbourhood Area". ${ }^{95}$ However, it seems that there will always be the option for LPAs to exclude such sites if they foresee that a neighbourhood forum might try to use the process to stifle development. This was stated to be a consideration by one of the officers of the LPA. There are competing considerations of justice that arise from this case, some of which appear to have been considered by the LPA, although not explicitly. One of the LPA's concerns was that if the strategic areas were included in the neighbourhood area, this would lead to a failure "to optimise the site's development potential" 96 and therefore lead to greater pressure on

\footnotetext{
89 TCPA 1990 s $61 \mathrm{G}(4)$.

${ }^{90} R$ (on the application of Daws Hill Neighbourhood Forum and others) $v$ Wycombe District Council [2013] EWHC 513 (Admin).

91 ibid, para 28 .

92 ibid.

93 ibid, para 42.

94 ibid, para 55.

95 ibid, para 53.

96 ibid, para 52.
} 


\section{Power to the People? The Impact of the Localism Act 2011 on Environmental Justice in England}

other areas and "the potential benefit of the site to the wider community may not be fully exploited". ${ }^{97}$

This is an issue theorised by Born and Purcell when arguing against the assumption that more local decisions are inherently more just. ${ }^{98}$ They state that localisation can as easily lead to greater injustices as it can to alleviating them. The authors point out that "if the local community is relatively rich, its economic gains will worsen injustices at a wider scale". ${ }^{99}$ This can be applied in a neighbourhood planning context. If residents of a relatively wealthy area are able to stifle strategic development in their area, thereby maintaining the affluence of that area, less affluent areas will inevitably be required to absorb a greater proportion of the burdens required to meet the priorities of the LDP. This would have a significant distributive effect and could lead to increased disparities between communities within the local authority area. Alternatively, by excluding these sites from the neighbourhood area there is the possibility that the residents of the neighbourhood are deprived of their right "to influence the type, design, location and mix of new development" ${ }^{100}$ that will undoubtedly have a significant impact on their living environment due to increased traffic flows and pressure on local amenities. This has implications for the procedural justice of such decisions.

A further issue that arises in this case is that it does not appear that any consideration has been given to the future. Neighbourhood forums are designated for a period of five years, after which time a new application must be made and considered. Conversely, neighbourhood areas once designated will subsist subject only to the LPA's ability to "modify designations already made" ${ }^{101}$ In the present case, there is no evidence that consideration was given to the future situation when the proposed development, including over 200 residences, has been completed. At this point, those who live in these new residences will automatically be excluded from 'the neighbourhood'. This is likely to increase any pre-existing feelings of 'them and us' and could lead to unnecessary division. Far from the Government's aim of "building stronger communities", it seems like decisions based solely on the snapshot situation could be inherently divisive. Whilst it is true that the new residents would be able to form their own neighbourhood forum and apply for a designated neighbourhood area, or at the end of five years to join a newly formed neighbourhood forum, it is easy to see that

\footnotetext{
${ }^{97}$ ibid.

${ }^{98}$ Branden Born and Mark Purcell, 'Avoiding the Local Trap: Scaling and Food Systems in Planning Research' (2006) 26 Journal of Planning Education and Research 195.

99 ibid, 202.

${ }^{100}$ Department of Communities and Local Government, An Introduction to Neighbourhood Planning, <www.communityplanning.net/pub-film/pdf/NeighbouthoodPlanning.pdf > .

${ }^{101}$ TCPA 1990 s 61G(6).
} 
tensions could arise out of this situation. When considering an application for designation of a neighbourhood area, the LPA must have regard to "existing boundaries"102 and inevitably, once boundaries are drawn they become very difficult to move.

A further example of the potentially divisive nature of delineating neighbourhoods can be seen in the example of Southbank and Bankside in London, concerning an area which is claimed by two adjoining neighbourhoods. This example shows the difficulties of casting aside administrative boundaries in favour of currently popular functional areas. The disputed area is within the administrative area of Southwark, as is the whole of the area of the Bankside proposal. The majority of the area covered by the Southbank proposal is in neighbouring Lambeth, but advocates state that the disputed area forms part of the natural neighbourhood and therefore administrative boundaries should be disregarded for this purpose. This has led to the rhetoric of a "turf war". ${ }^{103}$ Such disputes will inevitably lead to division within the area with different groups taking sides in the debate. This example clearly demonstrates the difficulties of drawing boundaries in urban settings and in how to define a community. People define themselves and their community in a variety of different ways which do not necessarily align themselves with any particular geographical location. Particularly in urban settings, a community is just as likely to be defined along lines of faith or shared interest as it is on an immediate locality based on residence. This lack of identification with an area is likely to lead to decreased levels of participation and interest in the process. Such a lack of identification was shown to have an effect in the regional context ${ }^{104}$ and is just as likely to be applicable at the neighbourhood level.

\section{Approval of Neighbourhood Forums}

In designating a neighbourhood forum, the LPA must ensure that the group is broadly representative of the area in question. ${ }^{105}$ This could prove very difficult to accomplish in practice. There is a requirement that the neighbourhood forum has at least 21 members. This must be seen in the context of the very different natures of the communities that such groups will represent. Of the bodies currently involved in neighbourhood planning, these discrepancies are clear. For example, the parish council of Appleton Wiske, a small village in

\footnotetext{
102 TCPA 1990 s 61G(4)(b).

103 'South Bank and Bankside in neighbourhood planning turf war' (London SE1 Community Website, 3 March 2013) <http://www.london-se1.co.uk/news/view/6671> accessed 6 August 2014.

${ }^{104}$ Fenwick et al state that "English regionalism has always been difficult to establish because few regions can plausibly claim a distinctive identity or culture". Fenwick et al (n 38) 10.

105 TCPA 1990 s 61F(7).
} 
North Yorkshire, has a registered electorate of 390 people, ${ }^{106}$ whilst the Friends of Fishwick and St Matthews represent approximately 12,000 residents in Inner East Preston. ${ }^{107}$ These are unlikely to be the most extreme examples, but obviously the challenges of ensuring that a 21person body is representative of 12,000 residents are greater than those of representing fewer than 500. Yet the Inner East Preston area is within one of the most deprived areas in England and resources available to devote to such investigations must be limited. This pattern is likely to be repeated across the country and is illustrated by the fact that in March 2013, London, with a population of approximately 8 million, and Herefordshire, with an approximate population of 180,000 , had the same number of NDPs in the process of being developed, at $15 .^{108}$

Several justice issues arise out of this situation. If an LPA lacks the resources to properly assess the representativeness of a group applying to become a neighbourhood forum, there is the potential that the system will be open to abuse by those with vested interests. Indeed, this accusation has been made in relation to an application for designation made to Hackney Council by Stamford Hill Neighbourhood Forum in relation to an area of North Hackney. ${ }^{109}$ Stamford Hill is home to the largest orthodox Jew community in the UK. Planning has historically been a contentious issue in the area. Some of the stated objectives of the Stamford Hill Neighbourhood Forum in relation to the proposed NDP are that there would be no requirement for planning permission for extensions to residential properties and there would be no requirement for planning permission for a change of use from residential to use as a religious school. A separate group known as North Hackney Neighbourhood Forum oppose these propositions. This has led to accusations of anti-Semitism and corruption on the part of local councillors ${ }^{110}$ and has led some to observe that "planning is simply too divisive

\footnotetext{
106 Planning Aid England 'Neighbourhood Planning Support: Appleton Wiske' (2013)

<http://www.rtpi.org.uk/media/1810653/appleton_wiske_case_study_jan_2013.pdf> accessed 6 August 2014.

107 Planning Aid England 'Neighbourhood Planning Support: Inner East Preston; (2013)

<http://www.rtpi.org.uk/media/1809761/inner_east_preston_case_study_jan_2013.pdf> accessed 6 August 2014.

108 'Localism push does little for disadvantaged' Planning Resource, 25 March 2013

<http://www.planningresource.co.uk/article/1175763/localism-push-does-little-disadvantaged/> accessed 6 August 2014.

109 Robert Booth 'Hackney planning row exposes faultlines in orthodox Jewish area' Guardian (London 8 March 2013) <http://www.theguardian.com/society/2013/mar/08/hackney-planning-row-orthdox-jewish> accessed 6 August 2014.

${ }^{110}$ Adam Barnett, 'Stamford Hill neighbourhood forum a front group for councillors, claim campaigners' (Hackney Citizen 19 January 2013) <www.hackneycitizen.co.uk/2013/01/19/stamford-hill-neighbourhoodhackney-planning-watch> accessed 6 August 2014.
} 
an issue in this part of the borough for a forum to work". ${ }^{111}$ In this event, Hackney Council has refused both applications, citing concern that to designate one or other would "exacerbate existing conflict" within the community. ${ }^{112}$ The experience in Hackney illustrates the tension that can be created, particularly in densely populated urban areas, of establishing unelected neighbourhood forums. In this instance, rather than promoting cohesion within the community, it has increased division and racial tension in the area.

The representativeness of a neighbourhood forum is also important because of the variety in the way that consultations are carried out. An advisor to Planning Aid England states that some forums have consulted the wider community on what sort of policies should be included in the plan, but others simply consult on pre-formed policies the forum has already devised. ${ }^{113}$ Without any clear guidance or policy on how such consultation should be carried out, the neighbourhood forum has a wide discretion. The decisions made at this stage are likely to have a significant impact on the content of any eventual NDP and as such it is essential that thought is given to the appropriateness of the designation.

In order to do this, however, an LPA must balance how best to utilise limited resources. At a time when budgets are shrinking it is questionable whether a planning officer's time should be used in assessing such issues rather than progressing the policies of the more democratically established LDP.

\section{The Referendum}

The importance of the make-up of the neighbourhood forum is accentuated by the referendum process by which an NDP is approved. As discussed above, a majority vote does not necessarily lead to a just outcome. It is therefore essential that as many interests as possible are represented by the group that decides upon the contents of the NDP. Planning decisions can have a profound effect on a small group of people and whilst this is not necessarily avoidable, such decisions must be made in a transparent and just way by accountable institutions rather than by a vocal majority.

\footnotetext{
${ }^{111}$ Richard Wilson, 'Hackney Planning Watch campaigners to petition council to say no to neighbourhood forums' (Hackney Citizen 8 May 2013) <http://hackneycitizen.co.uk/2013/05/08/hackney-planning-watchpetition-council-neighbourhood-forums/> accessed 6 August 2014.

${ }^{112}$ See Hackney Cabinet, 'Minutes of Meeting, 22 July 2013'

<mginternet.hackney.gov.uk/documents/g2391/Public reports pack 22nd-Jul-2013 18.00 Cabinet.pdf?T=10> 293 para 7.11, accessed 9 August 2014.

113 Telephone call, advisor to Planning Aid England to author (18 July 2013).
} 


\section{Urban v Rural Communities}

A further issue that arises is the difference of opportunities available in rural and urban areas. Recent figures show that the majority of NDP processes underway are in predominantly rural areas, and it is mainly "wealthy, professional types" 114 who are taking advantage of the process. Parish Councils generally exist in rural areas and, from a purely procedural standpoint, there are fewer hoops to jump through in these areas. Although the neighbourhood area does not have to cover the whole of the parish area, the existence of established boundaries in most cases will side-step any controversy. Another advantage for areas with a Parish Council is the pre-existing administrative structure. Such organisations have established funding routes and relationships with the local authorities. This traditional structure is a great advantage over the "major challenges"115 of starting from scratch.

The issues of creating a legitimately representative group in a densely populated urban area should not be underestimated. The only requirements under the Localism Act are that the local authority must consider the "desirability" of designating a group and they must consider that the group's "purpose reflects (in general terms) the character of that area".116 This is an extremely vague requirement and it is difficult to see how a decision made in relation to this requirement could be successfully challenged in the courts.

The issue of who participates in processes such as neighbourhood planning is discussed by Holman and Rydin in terms of "social capital" and they state that "one of the key aims... of localist planning will be to break the collective action problem that constrains participation [...] and engage a much wider cross-section of the local population". ${ }^{117}$ However, the challenge of involving the public beyond the 'usual suspects' should not be trivialised. Catney et al state that there is a need for a "reality check" in terms of what can be accomplished by community empowerment in practice. They state that in certain areas there is a lack of "community capacity" and that "people in some places are unable to marshal the necessary resources [...] to become self-organising and self-reliant". ${ }^{118}$ Encouraging participation in neighbourhood planning is likely to face significant obstacles, particularly in deprived communities. In general, people will only participate in a process where the benefit to them outweighs the costs of participation. Participation in neighbourhood planning will

\footnotetext{
${ }^{114}$ Planning Resource (n 108).

115 Jeff Bishop, 'From Parish Plans to Localism in England: Straight Track or Long and Winding Road?' (2010) 25 Planning Practice \& Research 611, 622.

116 TCPA 1990 s 61F(7)(a)(iii).

${ }^{117}$ Nancy Holman and Yvonne Rydin, 'What Can Social Capital Tell Us About Planning Under Localism?' (2013) 39 Local Government Studies 71, 77.

${ }^{118}$ Catney et al (n 27) 12.
} 
entail immediate costs to the participant. However, unlike traditional planning decisions, the outcomes of participation in neighbourhood planning are much more distant and uncertain. Further, participation in neighbourhood planning is likely to involve a greater investment by the participant. The process is not simply one of commenting on a proposal but devising the proposal itself, and in many cases producing the evidence to back up the proposal. It is likely that in many areas such planning policy is simply not enough of a concern in peoples' everyday lives to warrant the investment involved. As discussed above, the procedure involved in areas not represented by a Parish Council is extended and therefore the investment, in terms of time and organisation, required in these, mostly urban, areas is greater. However, it is exactly these areas where people are generally less likely to participate in such a process at all. This issue is illustrated by current figures, which show that only about 10 per cent of the current applications for designation of neighbourhood forums are in the 20 per cent most deprived local authority areas in England. ${ }^{119}$

A further issue of disparity between rural and urban communities is the mobility of individuals within those communities. Urban populations are more likely to be transient than the rural population. However, there is also likely to be a socio-economic element to mobility. Parvin points out that whilst advocates incorporate an idealistic notion of choice and freedom of movement into localism, in reality some people are "too poor, too busy or too dependent upon local support networks" $" 120$ to simply be able to uproot their lives and move, even if they strongly oppose certain local policies.

\section{The Role of Business}

One of the late changes to the process of neighbourhood planning was included in the 2011 Budget, which extended the right to create NDPs to businesses. This change was made under the pretext of encouraging economic growth. In the current atmosphere of austerity and public spending cuts, neighbourhood planning may well be a luxury many communities cannot afford. However, with the inclusion of local businesses in the process there may be the possibility for private investment in such processes. This may have unwelcome consequences and lead to businesses, and particularly developers, being the major influence in the process. This could result in the regulated developer becoming a part of the regulators' decision-

\footnotetext{
119 John Geoghegan, 'Poorer areas see few neighbourhood plan applications', Planning Resource $<$ http://planningresource.co.uk/article/1175787/poorer-areas-few-neighbourhood-plan-applications> accessed 5 August 2014.

120 Parvin (n 53) 356.
} 
making process. Decisions on this basis may be made by those that are supposed to be regulated by the system. This could lead to a situation known as regulatory capture.

Regulatory capture emerged as a concept relating to under-enforcement or poor enforcement of regulation. The theory is based on the 'revolving door' between the private and public sector, and therefore the regulated and regulator. It is suggested that those employed by regulators have either recently left the private sector or would like, at some point in the future, to join the private sector. Therefore, regulators often either have empathy with the regulated industries or do not want to upset them through concern for future employment opportunities. ${ }^{121}$ The concept has evolved and in this context relates to the involvement of regulated industry in the shaping of the regulations pertaining to that industry. Both aspects of the concept can be seen within the planning context. Most professional planners begin their career in the public sector and tend to leave to pursue more lucrative career opportunities once they have gained some experience. Consequently, planning consultants invariably know the system and are aware of any weaknesses that can be exploited. Often they will also be well aware of the individuals and the political context within which specific LPAs are operating. This gives the developers they represent an initial advantage over those who may oppose a proposed development. Here, however, the role that such developers (and their consultants) play in the creation of plans and policies is of greater concern.

As discussed above with regard to environmental impact assessments, developers often use procedures to their advantage to highlight the community benefits of a development such as job creation and strengthening of the local economy. It seems likely that the neighbourhood forum could simply be used as another opportunity for private developers to advertise these potential benefits and therefore influence the decision-making process. Even if this is not done intentionally or cynically, these factors are likely to influence residents of a deprived community to a far greater extent than they would a relatively affluent community. It is the deprived communities that are more likely to require the investment from the private sector in order to begin the neighbourhood planning process (whether in terms of money, time or expertise). This leads to a potential ransom situation where communities that wish to influence their local environment through the planning process simply hand over more power to private sector developers.

\footnotetext{
${ }^{121}$ See Toni Makkai and John Braithwaite, 'In and Out of the Revolving Door: Making Sense of Regulatory Capture' (1992) 12 Journal of Public Policy 61.
} 
An advisor to Planning Aid England reports that, to date, the private sector has generally ignored neighbourhood planning. ${ }^{122}$ However, he further states that where developers have been involved there have been strained relationships with the neighbourhood forum. In such situations, the developer has made assumptions about what policies will be proposed and a general assumption that they will aim to constrain development with associated accusations of NIMBYism.

It is important to consider the potential issues of involving the private sector in neighbourhood planning in the context of the current national economic situation. The economic downturn of the previous five years has led to huge cuts in public sector spending and consequently to local authority budgets. Further, the construction industry has been particularly affected by the recession, with a consequent decrease in development. ${ }^{123}$ These factors combine in various ways. The Coalition Government has made the planning system central to its priority of creating economic growth, stating that "planning reform is key to our economic recovery". ${ }^{124}$ There has been an increased push for efficiency in the planning system and a reduction in delays. Ruming states that where a planning system "promotes efficiency of assessment as a central outcome there is an increased possibility that 'client satisfaction' (ie development applicants) could supplant public interest as a key performance measure". ${ }^{125}$ The current changes to the planning system elevate the traditional private interest ideology of planning whilst limiting the ability of the system to promote the public interest and public participation. Procedural justice is likely to be affected by the inclusion of businesses in neighbourhood forums.

\section{CONCLUSIONS}

Environmental justice is inherently a local issue and land-use is fundamental to the living environment of communities. As such the Localism Act has the potential to have a momentous impact on environmental justice in England. Although only two aspects are concentrated on in this paper, the many changes made to the planning system by the Localism Act demonstrate the Coalition Government's commitment to a market-led system of

\footnotetext{
122 Telephone call, advisor to Planning Aid England to author (18 July 2013).

${ }^{123}$ Department for Business Innovation \& Skills, UK Construction: An Economic Analysis of the Sector (Crown Copyright 2013).

${ }^{124}$ Department for Communities and Local Government, 'Planning Reforms boost local power and growth' <https://www.gov.uk/government/speeches/planning-reforms-boost-local-power-and-growth> accessed 9 August 2014.

${ }^{125}$ Kristian Ruming, 'Negotiating Within the Context of Planning Reform: Public and Private Reflections from New South Wales, Australia' (2012) 17 International Planning Studies 397, 400.
} 
governance. It is equally clear from the Localism Act, as well as the general rhetoric of the country's leaders, that economic growth has taken precedence at the expense of social justice and environmental protection. As such, and despite its public declarations, sustainable development is not a main policy consideration of the current Government. Environmental justice in England is likely to suffer as a result.

In terms of land-use planning, it is generally accepted that RSSs were not perfect. There was little democratic accountability for the decisions made and the process was lengthy, complex, and allowed little in the way of meaningful public participation. In terms of procedural environmental justice, its credentials were questionable. However, it did allow a forum for making difficult decisions about the siting of unwanted land-uses and evidencebased assessments of regional needs. Because the abolition came relatively early in the life of most RSSs, it is difficult to factually assess their effectiveness in terms of distributive justice. At least from a theoretic standpoint it is likely that, despite the procedural shortcomings, RSSs may have led to greater justice in the distribution of both desirable and undesirable land-uses. The abolition of these strategic plans has in no way improved the position from a procedural point of view and has left a gap in the governance of planning which may well have a negative effect on distributive environmental justice in England.

In terms of neighbourhood planning, this paper has pointed to the many issues that are likely to arise, and in some cases already have, from its implementation. Overall, the problems arise from attempting to migrate a policy that works well in a rural setting into an urban one. Urban residents are far less likely to define their community in geographical terms and, as such, it becomes much more difficult to define a neighbourhood. This has led to disputes and, rather than strengthening community ties, has led to division and exclusion. Neighbourhood planning requires a much greater commitment than traditional participation in land-use planning decisions and some communities simply do not have the 'community capital' available to create an NDP. This is likely to have an adverse effect on both the procedural and the distributive aspects of environmental justice, as it seems that this new power is effectively only available to rural, middle class communities rather than the people as a whole. Socially deprived and ethnic minority communities will continue to struggle to find the resources required to take advantage of this new power as other concerns take precedence over the unknown and unpredictable long term impact of a NDP. 